\title{
Identifikasi Alternatif Pengembangan untuk Pemberdayaan Industri Kecil Hasil Peternakan Potensial di Kabupaten Bogor
}

\author{
M. Ridwan \\ Fakultas Peternakan Universitas Hassanuddin, Makassar
}

\begin{abstract}
The objectives of the study were to identify potency for development and possibilities for empowerment of small scale livestock product processing industries located in Bogor regency. A field survey has been conducted to collect information and data from some small scale industries which process different animal products of meat, milk, skin, bone, feather and slaughter house. Data collected included: human resources, capital, technology adapted, organization, product, marketing, government support, raw materials and market competitor. Data was analyzed by using the methods of AHP (Analytical Hierarchy Process) and Fuzzy NN - MCDM (Non Numeric Multi Criteria Decision Making). The results found that the most potency for development of small scale industry for animal product processing were the industries processing meat and milk. The most important aspect needed for empowerment was marketing.
\end{abstract}

Key words: livestock product industry, AHP and Fuzzy NN - MCDM

\section{Pendahuluan}

Industri kecil di Indonesia merupakan bagian penting dari sistem perekonomian nasional, karena berperan untuk mempercepat pemerataan pertumbuhan ekonomi melalui penyediaan lapangan kerja, peningkatan pendapatan dan ikut berperan dalam peningkatan perolehan devisa serta memperkokoh struktur industri nasional.

Menurut Hannan (2003), dari segi kuantitatif jumlah pelaku usaha di Indonesia tercatat 41,36 juta unit. Dari jumlah tersebut, sekitar 41,33 juta unit atau 99,9\% adalah usaha kecil menengah, sedangkan usaha skala besar hanya $0,005 \%$. Dengan jumlah yang dominan itu, usaha kecil dan menengah mampu menyerap 99,45 \% dari seluruh tenaga kerja nasional yang bekerja (sekitar 76,97 juta orang). Khusus pada sektor pertanian, peternakan, kehutanan dan perikanan, Usaha Kecil dan Menengah menyerap tenaga kerja sekitar $49 \%$.

Industri kecil sebagaimana perusahaan lainnya dalam mengelola bisnisnya perlu menerapkan strategi untuk hidup (cash flow) dan tumbuh (likuiditas) yang didukung oleh kompetensi yang baik (kreatif dan inovatif) dan kemampuan multi resources pooling yang dimilikinya, disamping proses marketing yang tepat, cepat dan andal untuk meraih keunggulan posisi maupun kinerja usaha. Dengan hal tersebut dapat diperkirakan, apakah bisnis yang dipilihnya dapat dikategorikan dalam model bisnis berpotensi tumbuh secara luas atau berpotensi berkembang terbatas.

Pengembangan sektor industri kecil sangat dipengaruhi oleh situasi makro ekonomi disamping kemam- 
puan internal industri kecil tersebut. Dalam kebijakan makro ekonomi pengembangan industri kecil bukan suatu prioritas, bahkan industri kecil cenderung diabaikan.

Perubahan lingkungan usaha saat ini memberikan dorongan untuk mengkaji ulang setiap kebijakan yang telah ambil pada masa lalu. Berbagai kebijakan dan inkosistensi dalam pelaksanaannya menyebabkan luka yang mendalam bagi kehidupan masyarakat. Untuk itu diperlukan reorientasi pola pengembangan dan pembinaan untuk dapat tumbuh dan berkembangnya industri kecil hasil peternakan di Indonesia. Dengan demikian dibutuhkan suatu strategi pemberdayaan industri kecil dan menengah untuk pengembangan produk unggulan di daerah masing masing.

Ketidakberhasilan pembinaan saat ini disebabkan karena ketidaktahuan pihak pembina (pemerintah) terhadap apa yang dibutuhkan industri kecil untuk dapat berkembang dan sukses. Kasus ini akan menentukan faktor - faktor prioritas untuk pengembangan industri kecil khusus industri hasil peternakan di kota Bogor.

Tujuan dari penelitian ini adalah untuk mengidentifikasi industri kecil hasil peternakan yang berpotensi untuk berkembang dan sukses di kabupaten Bogor serta alternatif komponen pengembangan untuk pemberdayaan industri kecil tersebut.

Penelitian ini mengkaji pengembangan industri kecil, khususnya industri kecil hasil peternakan yang ada di kabupaten Bogor yang mempunyai potensi untuk berkembang meliputi: industri pemotongan hewan, industri penyamak kulit, industri pengolahan susu, industri pengolahan tulang, industri pengolahan bulu, serta industri pengolahan daging. Kriteria penilaian didasarkan pada ketersediaan bahan baku, potensi pasar global, teknologi proses dan ketersediaan SDM pengelola.

\section{Materi dan Metode}

\section{Komponen Penilai Kriteria}

Komponen penilai yang mempunyai peran langsung dalam pengembangan industri kecil hasil peternakan di kabupaten Bogor adalah sebagai berikut:
1. Dinas Peternakan dan Perikanan Kabupaten Bogor
2. Dinas Perindustrian dan Perdagangan Kabupaten Bogor

3. Perwakilan Akademisi

\section{Kriteria dan Alternatif}

Dalam kasus ini untuk pemilihan industri kecil hasil peternakan prospektif menggunakan kriteria antara lain ketersediaan bahan baku, potensi pasar global, teknologi proses dan ketersediaan SDM pengelola dengan alternatif pilihan antara lain industri pemotongan, industri penyamakan kulit, industri pengolahan susu, industri pengolahan tulang, industri pengolahan bulu serta industri pengolahan daging. Sedangkan faktor pengembangan terdiri atas dua bagian utama yaitu faktor internal dan faktor eksternal yang dijabarkan dalam sembilan faktor meliputi: sumberdaya manusia, modal, teknologi, organisasi, produksi, pangsa pasar, dukungan pemerintah, bahan baku dan persaingan pasar. Sembilan faktor tersebut akan menjadi kriteria dalam penentuan alternatif kunci yang memerlukan pengembangan. Alter- 
natif tersebut yaitu peningkatan kemampuan produksi, peningkatan mutu produk, peningkatan aspek pemasaran serta peningkatan hubungan kemitraan.

\section{Skala Penilaian Kriteria}

Untuk memilih industri kecil hasil peternakan yang memiliki potensi untuk berkembang, digunakan metode AHP (Analitycal Hierarchy Process) yang dikembangkan oleh Saaty (1988) dengan skala perbandingan berpasangan. Adapun penilaian skala perbandingan berpasangan tersebut terlihat pada Tabel 1 .

\section{Penentuan Alternatif Pengem- bangan}

Penilaian terhadap masing masing kriteria digunakan penilaian sebagai berikut:

1. $\mathrm{PT}=$ Perfect (Paling Tinggi)

2. $\mathrm{ST}=$ Sangat Tinggi

3. $\mathrm{T}=$ Tinggi

4. $\mathrm{S}=$ Sedang

5. $\mathrm{R}=$ Rendah

6. $\mathrm{SR}=$ Sangat Rendah

7. $\mathrm{PR}=$ Paling Rendah

\section{Analisa Data}

a). Identifikasi Industri Kecil Potensial Penentuan industri kecil prospektif digunakan metode AHP (Analitycal Hierarchy Process) dengan bantuan software Criterium Decision plus 3.0.

Langkah - langkahnya sebagai berikut (Gambar 1).

1. Mengidentifikasikan masalah dan menentukan solusi yang diinginkan.

2. Membuat struktur hirarki yang diawali dengan tujuan umum, kriteria dan kemungkinan alternatif - alternatif.

3. Membuat matriks perbandingan berpasangan, melakukan perbandingan berpasangan yang menggambarkan kontribusi relatif atau pengaruh setiap elemen terhadap masing-masing tujuan dan kriteria yang setingkat diatasnya.

4. Melakukan perbandingan berpasangan sehingga diperoleh jumlah judgement dari responden sebanyak $\mathrm{n} \quad \mathrm{x}$ (n-1)/2, dimana $\mathrm{n}$ adalah banyaknya elemen.

Tabel 1. Skala Penilaian Perbandingan

\begin{tabular}{|c|l|}
\hline $\begin{array}{c}\text { Intensitas } \\
\text { Kepentingan }\end{array}$ & \multicolumn{1}{c|}{ Keterangan } \\
\hline 1 & Kedua elemen sama pentingnya \\
\hline 3 & Elemen yang satu sedikit lebih penting dari elemen yang lain \\
\hline 5 & Elemen yang satu lebih penting dari elemen yang lain \\
\hline 7 & Satu elemen jelas lebih penting dari elemen yang lain \\
\hline 9 & Satu elemen mutlak lebih penting dari elemen yang lain \\
\hline $2,4,6,8$ & Nilai - nilai diantara kedua nilai pertimbangan yang berdekatan \\
\hline
\end{tabular}

Sumber: Saaty (1988) 
5. Menghitung eigen value dan menguji konsistensinya dengan menggunakan rasio konsistensi sebagai ukuran (CR) dan besarnya CR yang ditolerir adalah tidak lebih dari $10 \%$. Jika tidak konsistensi maka pengambilan data diulangi.

Adapun persamaan - persamaan yang digunakan adalah sebagai berikut :

- Menghitung eigen value setiap baris :

$$
\lambda_{i}=\sum_{j=i}^{N} a_{i j} \frac{W_{i}}{W_{j}}
$$

- Menghitung eigen vector setiap baris :

$$
(E V)_{k}=\frac{1}{N} \sum_{j=i}^{N} \frac{a_{k j}}{\sum_{i=j}^{N} a_{i j}}
$$

- Menghitung $\lambda_{\text {maks }}$ :

$$
\lambda_{\text {maks }}=\frac{1}{N} \sum_{i=1}^{N} \lambda_{i}
$$

- Menghitung konsistensi ratio setiap baris :

$$
C R=\frac{C I}{N R C}
$$

$\mathrm{NRC}=$ bilangan konsistensi random

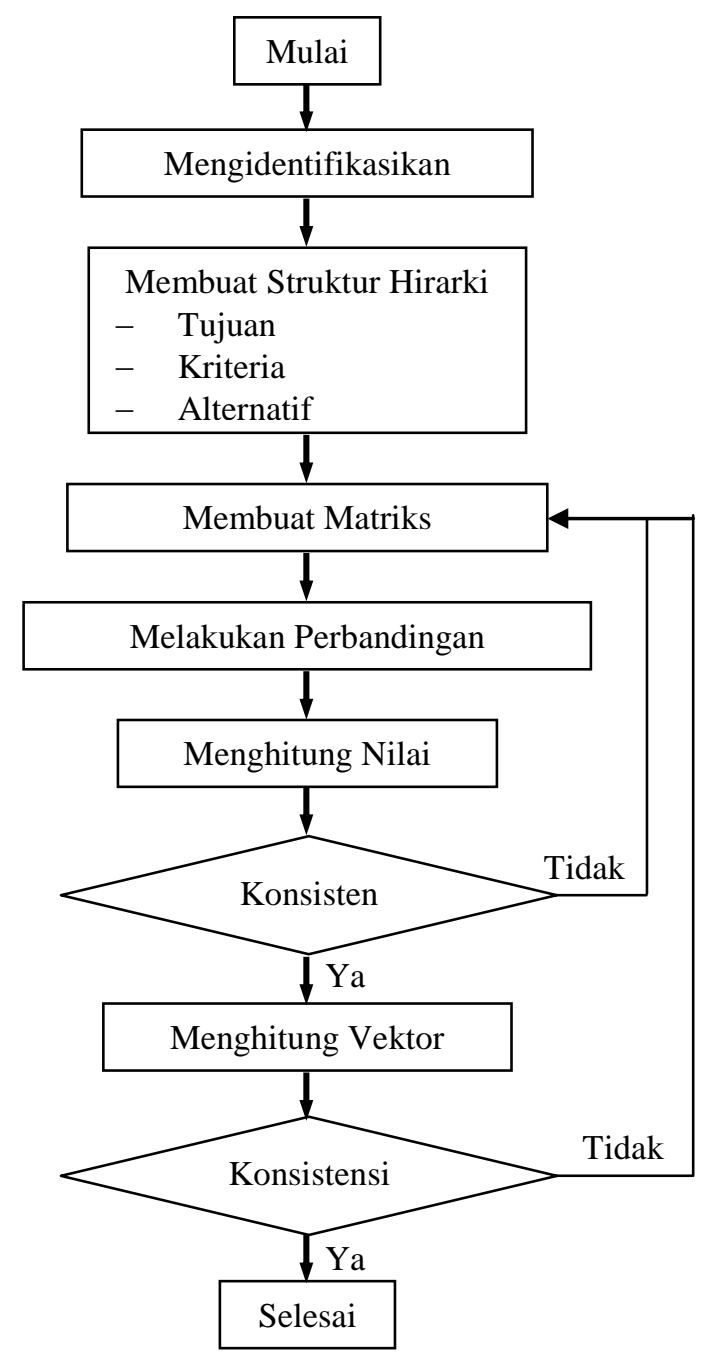

Gambar 1. Tahapan Pemilihan Industri Kecil Hasil Peternakan Prospektif. 
b). Penentuan Alternatif Pengembangan

Prioritas pengembangan untuk pemberdayaan industri kecil terpilih dapat dilakukan dengan menggunakan metode "non-numeric multicriteria multi-person decision making" yang dikembangkan oleh Yager (1993), menggunakan operasi negasi dan "Ordered Weighted Averaging (OWA)" operator.

Operasi negasi dilaksanakan dengan rumus sebagai berikut :

$$
\begin{aligned}
& \boldsymbol{W}_{\boldsymbol{k}}=\boldsymbol{W}_{q-k+1} \\
& \text { dimana : } \\
& \mathrm{q} \quad=\text { jumlah skala } \\
& \mathrm{k} \quad=\text { kriteria ke - }
\end{aligned}
$$

Penentuan setiap kriteria oleh penilai ditentukan melalui rumus :

$$
\begin{aligned}
& \boldsymbol{P}_{i k}=\operatorname{Min}_{j}\left[\operatorname{Neg}\left\{I\left(q_{j}\right)\right\}_{\vee} \boldsymbol{P}_{i k}\left(q_{j}\right)\right] \\
& \text { dimana : } \\
& \mathrm{P}_{\mathrm{ik}}=\text { nilai dari penilai } \mathrm{ke} \mathrm{k} \\
& \text { untuk kriteria ke - i } \\
& \mathrm{I}\left(\mathrm{q}_{\mathrm{i}}\right)=\text { nilai kepentingan kriteria } \\
& \mathrm{P}_{\mathrm{ik}}\left(\mathrm{q}_{\mathrm{i}}\right)=\text { nilai tingkat kepentingan } \\
& \text { untuk kriteria ke i oleh } \\
& \text { penilai } \mathrm{ke}-\mathrm{k} \\
& \mathrm{V} \quad=\text { notasi maksimum } \\
& \mathrm{i} \quad=1,2,3, \ldots . \mathrm{n} \\
& \mathrm{k} \quad=1,2,3,4,5 \\
& \mathrm{j}=\text { kelompok kriteria }
\end{aligned}
$$

Mengagregasi tingkat penilaian dilakukan dengan menggunakan bobot kepentingan kelompok penilai dengan rumus :

$$
\mathbf{P}_{\mathbf{i}}=\mathbf{f}\left(\mathbf{P}_{\mathrm{i}}\right)=\operatorname{Max}\left(\mathbf{W}_{\mathrm{k}} \wedge \mathbf{b}_{\mathrm{k}}\right)
$$

dimana :

$\mathrm{P}_{\mathrm{i}}=$ nilai untuk kriteria $\mathrm{ke}-\mathrm{i}$

$\mathrm{k} \quad=$ kelompok penilai

$\mathrm{W}_{\mathrm{k}} \quad=$ bobot kepentingan kelompok penilai

$b_{k}=$ nilai, diurut dari besar ke kecil.

\section{Hasil dan Pembahasan}

\section{Identifikasi Industri Kecil Hasil Peternakan Potensial}

Untuk merencanakan kepentingan industri kecil hasil peternakan di kabupaten Bogor digunakan analisa AHP (Analytical hierarchy Process) dengan kriteria (1) ketersediaan bahan baku, (2) kemampuan sumberdaya manusia, (3) potensi pasar dan (4) tingkat penggunaan teknologi. Setiap kriteria mempunyai koefisien pembobot dengan menggunakan analisis perbandingan berpasangan full parwaise.

Dari hasil analisa diperoleh bahwa dari keempat kriteria yang digunakan potensi pasar $(0,448)$ adalah merupakan kriteria yang paling utama, disusul kriteria ketersediaan bahan baku $(0,303)$, kemampuan SDM $(0,149)$ dan penguasaan teknologi $(0,101)$, sehingga untuk pengembangan industri kecil hasil peternakan di kabupaten Bogor, faktor potensi pasar harus menjadi pertimbangan utama. Untuk lebih lengkapnya bobot masing masing kriteria disajikan pada Tabel 2. 
Tabel 2. Bobot Kriteria dalam Identifikasi Industri Kecil Hasil Peternakan Potensial di Kabupaten Bogor

\begin{tabular}{|c|l|c|}
\hline No & \multicolumn{1}{|c|}{ Kriteria } & Bobot \\
\hline 1 & Potensi pasar & 0,432 \\
\hline 2 & Ketersediaan bahan baku & 0,311 \\
\hline 3 & Kemampuan SDM & 0,187 \\
\hline 4 & Penggunaan teknologi & 0,070 \\
\hline
\end{tabular}

Tabel 3. Rangking Industri Kecil Hasil Peternakan Potensial di Kabupaten Bogor

\begin{tabular}{|c|l|c|}
\hline No. & Jenis Industri Kecil & Bobot \\
\hline 1 & Pengolahan daging & 0,259 \\
\hline 2 & Pengolahan susu & 0,253 \\
\hline 3 & Pemotongan & 0,245 \\
\hline 4 & Pengolahan kulit & 0,120 \\
\hline 5 & Pengolahan tulang & 0,063 \\
\hline 6 & Pengolahan bulu & 0,061 \\
\hline
\end{tabular}

Dengan menggunakan empat kriteria tersebut dan analisa AHP, maka dapat diperoleh rangking industri kecil hasil peternakan potensial untuk kabupaten Bogor beserta bobot masing - masing. Industri kecil hasil peternakan yang paling potensial adalah industri kecil pengolahan daging $(0,259)$ kemudian disusul industri kecil pengolahan susu $(0,253)$, dan industri pemotongan $(0,242)$. Ketiga jenis tersebut bersumber dari produk hasil peternakan utama yaitu daging dan susu, sedangkan tiga kategori industri pengolah lainnya yaitu industri pengolahan kulit $(0,122)$, industri pengolahan tulang $(0,062)$ dan industri pengolahan bulu $(0,061)$ sebagai industri kecil pengolah hasil sampingan usaha peternakan dianggap kurang potensial untuk kabupaten Bogor berdasarkan data tersebut diatas. Untuk lebih jelasnya dapat dilihat pada Tabel 3 .

Dari hasil tersebut diatas dapat disimpulkan bahwa untuk pengembangan industri kecil hasil peternakan di kabupaten Bogor sebaiknya difokuskan pada industri kecil pengolahan hasil peternakan utama yaitu pengolahan daging dan susu, sedangkan untuk pengolahan hasil sampingan usaha peternakan berupa kulit, tulang dan bulu adalah kurang potensial untuk Kabupaten Bogor.

\section{Alternatif Pengembangan Industri Kecil Hasil Peternakan \\ Dalam upaya pemberdayaan industri kecil hasil peternakan po- tensial telah diidentifikasi sebe- lumnya, yaitu pengolahan daging, susu dan industri pemotongan, maka dilakukan suatu analisis untuk}


mengetahui bagian yang perlu mendapat perhatian khusus untuk meningkatkan kemampuan industri kecil tersebut. Dalam analisis ini diberikan empat alternatif utama yang perlu difokuskan, yang umumnyamenjadi faktor kunci berkembangnya industri kecil tersebut, yaitu peningkatan kemampuan produksi, peningkatan mutu produk, peningkatan kemampuan pemasaran dan peningkatan hubungan kemitraan dengan menggunakan sembilan kriteria dan bantuan analisis perbandingan berpasangan full parwaise, maka diperoleh bobot kriteria sebagaimana tercantum pada Tabel 4.

Mengingat keterbatasan biaya, dana dan waktu maka perlu dilakukan prioritas pengembangan untuk pemberdayaan tersebut. Adapun hasil analisis menggunaka Fuzzy Non Numeric Multi Criteria Decision Making dengan bantuan Ordering Weighted Averaging $(O W A)$ operator sebagaimana terlihat pada Tabel 5.

Berdasarkan dua hasil analisis dengan Fuzzy NN-MCDM dengan bantuan OWA operator pada Tabel 7, dapat dilihat bahwa dalam upaya pemberdayaan industri kecil hasil peternakan di kabupaten Bogor, faktor kunci yang harus mendapat prioritas utama adalah peningkatan kemampuan pemasaran, dalam hal ini pihak yang berkompeten harus mampu memberikan akses untuk pemasaran produk hasil dari industri kecil tersebut baik dalam maupun luar negeri.

Tabel 4. Bobot Kritera dalam Penentuan Alternatif Pengembangan untuk Pemberdayaan Industri Kecil Hasil Peternakan di Kabupaten Bogor

\begin{tabular}{|c|l|c|c|c|}
\hline No & \multicolumn{1}{|c|}{ Kriteria } & Bobot & Label & Rangking \\
\hline 1 & Kemampuan SDM & 0,197 & PT & 1 \\
\hline 2 & Ketersediaan modal & 0,166 & ST & 2 \\
\hline 3 & Penggunaan teknologi & 0,113 & R & 4 \\
\hline 4 & Organisasi & 0,085 & SR & 6 \\
\hline 5 & Kemampuan produksi & 0,101 & R & 5 \\
\hline 6 & Pangsa pasar & 0,128 & S & 3 \\
\hline 7 & Dukungan pemerintah & 0,052 & PR & 9 \\
\hline 8 & Ketersediaan bahan baku & 0,083 & SR & 7 \\
\hline 9 & Persaingan pasar & 0,074 & SR & 8 \\
\hline
\end{tabular}


Tabel 5. Matriks Penilaian Responden terhadap Beberapa Alternatif, Berdasarkan Masing - masing Kriteria

\begin{tabular}{|c|c|c|c|c|c|c|c|c|c|c|}
\hline \multirow{2}{*}{ Resp } & \multirow{2}{*}{$\begin{array}{l}\text { Alternatif } \\
\text { Peningkatan }\end{array}$} & \multicolumn{9}{|c|}{ Kriteria $\left.^{*}\right)$} \\
\hline & & 1 & 2 & 3 & 4 & 5 & 6 & 7 & 8 & 9 \\
\hline \multirow{4}{*}{1} & Aspek Produksi & $S$ & $P T$ & $S T$ & $S$ & $P T$ & $S$ & $R$ & $P T$ & $R$ \\
\hline & Mutu Produk & $S T$ & $S T$ & $P T$ & $S$ & $S T$ & $S T$ & $R$ & $S$ & $R$ \\
\hline & Aspek Pemasaran & $P T$ & $T$ & $S$ & $S T$ & $S$ & $P T$ & $P T$ & $R$ & $P T$ \\
\hline & Hub. Kemitraan & $T$ & $S$ & $R$ & $P T$ & $S$ & $S T$ & $S T$ & $T$ & $S T$ \\
\hline \multirow{4}{*}{2} & Aspek Produksi & $S T$ & $P T$ & $S T$ & $S T$ & $S T$ & $S T$ & ST & $S$ & $T$ \\
\hline & Mutu Produk & $S$ & $T$ & $T$ & $T$ & $T$ & $T$ & $T$ & $T$ & $S$ \\
\hline & Aspek Pemasaran & $S T$ & $T$ & $T$ & $T$ & $S T$ & $S T$ & $T$ & $S T$ & $S T$ \\
\hline & Hub. Kemitraan & $T$ & $S T$ & $S$ & $S T$ & $T$ & $S$ & $T$ & $S$ & $T$ \\
\hline \multirow{4}{*}{3} & Aspek Produksi & $S$ & $S$ & $S$ & $R$ & $S$ & $P T$ & $S$ & $S$ & $T$ \\
\hline & Mutu Produk & $S$ & $R$ & $S$ & $R$ & $S$ & $S T$ & $S$ & $S$ & $T$ \\
\hline & Aspek Pemasaran & $S$ & $R$ & $R$ & $S R$ & $R$ & $S$ & $R$ & $R$ & $R$ \\
\hline & Hub. Kemitraan & $S$ & $S$ & $S$ & $S R$ & $S$ & $T$ & $T$ & $R$ & $T$ \\
\hline terang & $\begin{array}{l}\text { 1. SDM } \\
\text { 2. Modal } \\
\text { 3. Teknologi }\end{array}$ & & odu & Pasar & & & $\begin{array}{l}\text { Bak } \\
\text { agan }\end{array}$ & & & \\
\hline
\end{tabular}

Tabel 6. Hasil Agregasi Kriteria untuk Masing - masing Alternatif

\begin{tabular}{|c|c|c|c|c|}
\hline \multirow{2}{*}{ Responden } & \multicolumn{4}{|c|}{ Alternatif Pengembangan } \\
\cline { 2 - 5 } & $\begin{array}{c}\text { Aspek } \\
\text { Produksi }\end{array}$ & Mutu Produk & $\begin{array}{c}\text { Aspek } \\
\text { Pemasaran }\end{array}$ & $\begin{array}{c}\text { Hubungan } \\
\text { Kemitraan }\end{array}$ \\
\hline 1 & $S$ & $S T$ & $T$ & $S$ \\
\hline 2 & $S T$ & $S$ & $T$ & $S$ \\
\hline 3 & $S$ & $R$ & $R$ & $S$ \\
\hline
\end{tabular}

Tabel 7. Hasil Agregasi Penilaian Responden dengan OWA Operator

\begin{tabular}{|l|c|c|}
\hline \multicolumn{1}{|c|}{$\begin{array}{c}\text { Alternatif } \\
\text { Pengembangan }\end{array}$} & Bobot & Keterangan \\
\hline Aspek Produksi & $S$ & \\
\hline Mutu Produk & $S$ & Prioritas Utama \\
\hline Aspek Pemasaran & $T$ & \\
\hline Hub. Kemitraan & $S$ & \\
\hline
\end{tabular}

\section{Kesimpulan}

Berdasarkan hasil penelitian dapat ditarik kesimpulan sebagai berikut :

1. Industri kecil hasil peternakan yang potensial untuk kabupaten Bogor, secara berturut - turut berdasarkan bobot kepentingan yaitu industri kecil pengolahan daging $(0,259)$, industri kecil pengolahan susu $(0,252)$ dan industri kecil pemotongan $(0,242)$.

2. Untuk pemberdayaan industri kecil hasil peternakan di 
kabupaten Bogor, maka peningkatan kemampuan pemasaran adalah merupakan prioritas uatama yang harus mendapat perhatian pemerintah dan semua pihak yang berkompeten.

\section{Daftar Pustaka}

Marimin, M. Hatono, I. Tamura. 1997. Non Numeric Methode For Parwaise Fuzzy Group decision Analysis dalam Journal Of Intelegent and Fuzzy System. Vol $5: 257-269$.

Saaty, T.L. 1986. Pengambilan Keputusan Bagi Para Pemimpin.

Alamat korespondensi: Muh. Ridwan Jurusan Sosial Ekonomi Peternakan Fakultas Peternakan Universitas Hassanuddin Makassar.

Artikel diterima: 12 Januari 2004, disetujui: 2 Desember 2004

\footnotetext{
Artikel diterima: 12 Januari 2004, disetujui: 2 Desember 2004
}

PT. Pustaka Binaman Pressindo, Jakarta.

Saragih, B. 1998. Agribisnis Berbasis Peternakan. Kumpulan Pemikiran. Institut Pertanian Bogor. Bogor.

Yudhistrita, T.L. 1998. Pengembangan Metode Analytical Hierarchy Process (AHP) Berdasarkan Teori Probabilitas dan Himpunan Fuzzy dalam Jurnal Teknik dan Manajemen Industri ITB. Vol $18: 3$, Desember. Institut Teknologi Bandung. Bandung. 